\title{
Energy effective drying modes of soy-vegetable compositions
}

\section{Zhanna Petrova, Kateryna Slobodianiuk}

\section{Institute of Technical Thermophysics of the National Academy of Sciences of Ukraine, Kyiv, Ukraine}

Keywords:

Drying

Moisture transfer

Soybean

Carrot

Spinach

Heat-coolant

Article history:

Received 24.04.2017

Received in revised

form 20.06.2017

Accepted 05.09.2017

\section{Corresponding author:}

Kateryna Slobodianiuk E-mail:

slobod_katya@ukr.net

DOI: $10.24263 / 2310-$

1008-2017-5-1-15

\section{Abstract}

Introduction. It was carried out the research for determining the optimal drying conditions of soybean and vegetable mixtures that provide the least drying time and maximally preserve the biologically active substances of the dried material.

Materials and methods. It was researched the colloidal capillary-porous materials on the basis of soy, carrots, spinach and soy-carrot, soy-spinach mixture. For the study of the drying process it was used an experimental stand with automatic temperature controllers was used which is a system of isolated pipelines with devices for heat treatment and circulation of coolant, drying chambers, measuring circuits and instruments for controlling the process parameters and measuring the values characterizing the process of drying.

Results and discussion. Researched the kinetics of the soybean-carrot mixture drying process at a temperature of the coolant temperature of $70{ }^{\circ} \mathrm{C}, 100{ }^{\circ} \mathrm{C}$, with a constant drying rate $\mathrm{v}=2.5 \mathrm{~m} / \mathrm{s}$, as well as mode steps of $100 / 70^{\circ} \mathrm{C}$ with constant drying rate $\mathrm{v}=2.5 \mathrm{~m} / \mathrm{s}$. The process of drying the binary mixture takes place in the second period. With the deepening of the evaporation zone inside the material, the temperature of its surface increases, and the rate of moisture content decreases. It has been established that drying with a temperature of the coolant temperature of $100^{\circ} \mathrm{C}$ results in an inadmissible melaidine reaction, while the $100 / 70{ }^{\circ} \mathrm{C}$ step mode prevents such reactions due to the fact that the material does not warm up above 70 degrees throughout the drying period.

Researched the kinetics of the soybean-spinach mixture drying process at a temperature of $60{ }^{\circ} \mathrm{C}$, as well as mode steps of $100 / 60$ ${ }^{\circ} \mathrm{C}$, a constant drying rate $\mathrm{v}=2.5 \mathrm{~m} / \mathrm{s}$. In the chemical composition of spinach contains folic acid, which is destroyed during the heat treatment of products at a temperature of $100{ }^{\circ} \mathrm{C}$ for 20 minutes. When drying the mixture with a $100 / 60^{\circ} \mathrm{C}$ degree of temperature, the material under investigation at a temperature of the heat carrier is $100{ }^{\circ} \mathrm{C}$ for 4 minutes, and then the temperature of the coolant is reduced, after 20 minutes of drying the temperature of the coolant $80^{\circ} \mathrm{C}$, this prevents significant losses of folic acid, after 40 minutes of drying, the temperature of the coolant is $60^{\circ} \mathrm{C}$, during the whole process of drying the surface temperature and in the thickness did not exceed $60^{\circ} \mathrm{C}$.

Conclusions. The drying time of the material in the mode of the heat carrier $100 / 60{ }^{\circ} \mathrm{C}$ and $100 / 70{ }^{\circ} \mathrm{C}$ is less in comparison with the duration of the process at 60 and $70{ }^{\circ} \mathrm{C}$, which reduces energy expenses by $30-40 \%$ for the drying process. 


\section{Introduction}

Processes of drying vegetable raw materials are an important issue for preserving food [1], in which water removal minimize many of the moisture-driven deterioration reactions impacting the bioproduct quality. Dried fruits and vegetables and their application in powder form have gained interest in the food industry. Drying and grinding conditions during powder processing greatly influence the quality attributes of biological materials. It implies not only nutritional changes but also physical, textural, sensorial and functional changes [2]. It is known that the main mechanism for removing moisture is the diffusion of fluid. This mechanism is complex due to the diversity of the chemical composition and physical structure of the material [3].

Knowledge of thermodynamic properties during the process of drying of plant materials allows designing drying equipment, calculating the energy required in the process, studying the properties of the adsorbed liquid, assessing the microstructure of food products, and studying the physical phenomena occurring on the material surface [3]. Due to the lack of research in the literature that provides information on changes in moisture in soybean-carrots and soy-spinach mixtures, this work is aimed at studying the process of drying soybean plants to achieve the energy efficiency of the process.

Soybeans are rich in nutrients and biologically active substances. Soya is associated with the reduction of some diseases such as heart disease, hypertension, breast cancer and cholesterol [4]. The use of soy ingredients in foods is receiving significant attention from the food industry and consumers because of their role as a functional food. The functionality of food can be addressed from the perspective of food components. Despite the rich health benefits of soy ingredients and affordability, their use in widely consumed dairy products needs further study [5].

Carotenoids are colourful compounds, present in fruits and vegetables, synthesised by plants andmicro-organisms. About 10\% of these are important dietary precursors of vitamin A. Carotenoidsact as antioxidants and possibly decrease in-vivo lipid oxidation. Lipid oxidation is known to be arisk factor for atherosclerosis [6].

In soy-carotene-containing powders, high lipid content up to $40 \%$ [7]. Carotenoids, in the process of storing soy-vegetable compositions, help to stabilize and prevent the process of oxidation of soy proteins.

\section{Materials and methods}

\section{Materials}

To develop energy-efficient drying modes of soybean and vegetable compositions the research was carried out on plant material, such as: pre-hydrothermal processing soybean [8], carrots and spinach, as well as mixtures-soy-spinach and soybean-carrot.

\section{Chemical composition of soy}

Generally soybean seeds content $5,6-11.5 \%$ of water, ranges for crude protein is from 32 to $43,6 \%$, for fat from 15.5 to $24.7 \%$, for crude ash from 4.5 to $6.4 \%$, for neutral detergent fiber (NDF) from 10 to $14,9 \%$, acid detergent fiber (ADF) from 9 to $11,1 \%$, carbohydrates content from 31.7 to $31.85 \%$ on a dry matter basis [9]. 
Soybean meal is the best vegetable protein source considering on quantity as well its quality. From among legume seeds, the soybean seeds content the most of crude protein and the best of amino acid composition. Content of crude fiber (about 6\%) is lower in comparison to another vegetable high protein feeds [9].

Soybean seeds contain to $40 \%$ of crude protein and about $20 \%$ of fat, and soybean meal characterized higher content of crude protein - about $40-49 \%$. The protein of soybean contains the considerable quantity of lysine $(6.2 \mathrm{~g} / 16 \mathrm{gN})$, but value of protein is limited by methionine and cystine content $(2.9 \mathrm{~g} / 16 \mathrm{gN})$ [9].

The nutritive value of soybean is limiting mainly by trypsin and chymotrypsin inhibitors, pectins and the protein about immunology activity. The most important there are the trypsin inhibitors - the Kunitz inhibitors and the Bowman-Birk inhibitors. Protease inhibitors (the Kunitz inhibitor and Bowman-Birk inhibitor) are active against trypsin and chymotrypsin. These inhibitors interfere with the digestion of proteins. Activity of trypsin inhibitor range from 100 to $184 \mathrm{TUI} / \mathrm{mg}$ of protein. The limit of activity for soy products is to 0.4 urease units. Thacker \& Kirkwood report a range for trypsin inhibitors of 21.1 to 31.1 $\mathrm{mg} / \mathrm{g}$. The activity of these inhibitors in soybean products may be decrease by toasted or heated processes. The right warming up of soybean and its products eliminate above $90 \%$ of antitrypsin activity [9].

\section{Chemical composition of carrot}

The moisture content of carrot varies from 86 to $89 \%$. Carrots are a good source of carbohydrates and minerals like $\mathrm{Ca}, \mathrm{p}, \mathrm{Fe}$ and $\mathrm{Mg}$. Gopalan have reported the chemical constituents of carrot as moisture $(86 \%)$, protein $(0.9 \%)$, fat $(0.2 \%)$, carbohydrate $(10.6 \%)$, crude fiber (1.2\%), total ash (1.1\%), Ca (80 mg/100 g), Fe (2.2 mg/100 g) and p (53 mg/100 g) whereas, the values reported by Holland for most of these parameters are different i.e. moisture $(88.8 \%)$, protein $(0.7 \%)$, fat $(0.5 \%)$, carbohydrate $(6 \%)$, total sugars $(5.6 \%)$, crude fiber $(2.4 \%), \mathrm{Ca}(34 \mathrm{mg} / 100 \mathrm{~g}), \mathrm{Fe}(0.4 \mathrm{mg} / 100 \mathrm{~g}), \mathrm{p}(25 \mathrm{mg} / 100 \mathrm{~g}), \mathrm{Na}(40 \mathrm{mg} / 100 \mathrm{~g}), \mathrm{K}$ (240 mg/100 g), Mg (9 mg/100 g), Cu (0.02 mg/100 g), Zn (0.2 mg/100 g), carotenes (5.33 $\mathrm{mg} / 100 \mathrm{~g})$, thiamine $(0.04 \mathrm{mg} / 100 \mathrm{~g})$, riboflavin $(0.02 \mathrm{mg} / 100 \mathrm{~g})$, niacin $(0.2 \mathrm{mg} / 100 \mathrm{~g})$, vitamin C (4 mg/100 g) and energy value $(126 \mathrm{~kJ} / 100 \mathrm{~g})$ [10]. The edible portion of carrots contains about $10 \%$ carbohydrates having soluble carbohydrates ranging from 6.6 to 7.7 $\mathrm{g} / 100 \mathrm{~g}$ and protein from 0.8 to $1.1 \mathrm{~g} / 100 \mathrm{~g}$ in 4 carrot cultivars. Kaur have reported 1.67 $3.35 \%$ reducing sugars, $1.02-1.18 \%$ non-reducing sugars and $2.71-4.53 \%$ total sugars in 6 cultivars of carrot. Simon and Lindsay reported that reducing sugars accounted for $6-32 \%$ of free sugars in 4 hybrid varieties of carrot [10]. The free sugars identified are sucrose, glucose, xylose and fructose. The crude fiber in carrot roots consist of $71.7,13.0$ and $15.2 \%$ cellulose, hemicllulose and lignin, respectively. The cellulose content in 4 carrot varieties varied from 35 to $48 \%$. The average nitrate and nitrite content in fresh carrot have been 40 and $0.41 \mathrm{mg} / 100 \mathrm{~g}$, respectively. The taste of carrots is mainly due to the presence of glutamic acid and the buffering action of free amino acids [10]. Trace amounts of succinic acid, $\alpha$-ketoglutaric acid, lactic acid and glycolic acid have also been reported. Caffeic acid is the predominant phenolic acid in carrots. Thiamin, riboflavin, niacin, folic acid and vitamin $\mathrm{C}$ are present in appreciable amounts in carrot roots. The anthocyanins content in roots may vary from trace amounts in pink cultivars to $1,750 \mathrm{mg} / \mathrm{kg}$ in black carrots. The major anthocyanins have been identified as cyanidin 3-(2-xylosylgalactoside), cyanidin 3xylosylglucosylgalactoside and cyanidin 3-ferulylxyloglucosyl galactoside [10]. 


\section{Chemical composition of spinach}

Spinach is one of the most important antioxidative vegetables, usually consumed after boiling either fresh or frozen leaves. Freshly cut spinach leaves contain approximately $1,000 \mathrm{mg}$ of total flavonoids per kilogram. The possible presence of flavonoid-like compounds in spinach was first reported in 1943 but nearly $20 \mathrm{yr}$ elapsed before the structure of the flavonol isolated from spinach leaves was established as patuletin and the presence of spinacetin was confirmed [11]. In addition, the existence of several flavonol glycosides in a methanolic extract of spinach leaves was reported. The occurrence of at least 10 flavonoid glycosides has now been reported in spinach [11]. These are glucuronides and acylated di-and triglycosides of methylated and methylene dioxide derivatives of 6-oxygenated flavonols [11]. Glucuronides are more water-soluble than glycosides and acylated compounds that remain in the tissue after cooking in boiling water. Flavonoids and other phenolic constituents act as antioxidants by the free-radical scavenging properties of their hydroxyl groups. Extensive conjugation across the flavonoid structure and numerous hydroxyl groups enhance their antioxidative properties, allowing them to act as reducing agents, hydrogen-orelectron-donatingagents, orsinglet-oxygen scavengers. Results from the in vitro oxygen radical absorbance capacity (ORAC) assay have shown that, among various fruit and vegetable extracts, foods with the highest ORAC activity include spinach, strawberries, and blueberries [11]. The antioxidant capacity of spinach flavonoidshasbeendeterminedbythefree-radicalscavenging assay using DPPH radical and was compared with that of Trolox, a synthetic analogue of vitamin E. The most active products were those derived from patuletin with a 3,4-dihydroxyl group [11]. The incorporation of a feruloyl residue increased the free-radical scavenging activity. During storage of spinach leaves, a decrease in the total antioxidant activity was observed. Boilingof fresh-cut spinach leaves extracted approximately $50 \%$ of the total flavonoids and $60 \%$ of the vitamin $\mathrm{C}$ in cooking water; however, flavonoid glucuronides were extracted more than other glycosides [11].

\section{Experimental stand}

Investigation of convective drying processes was carried out on an experimental stand, the principal scheme of which is depicted in Figure 1 [14].

The experimental stand consists [12] of a system of isolated air ducts with devices for heating and circulation of coolant, drying chambers, measuring circuits and instruments for controlling the process parameters and measuring the quantities characterizing the process of drying the test material.

The drying chamber 1 is a rectangular sheet of iron with a manhole for the introduction of samples of the material. The chamber has lateral clear hatches, through which you can observe the state of the material during the drying process. The design of the stand allows conducting the study of the drying process by weight, using the scales connected to the computer.

The heat-training section of air (2) is made in the form of a rectangular box, which contains electric heaters, which allow to maintain in the automatic mode the temperature of air in a wide range. The automatic temperature control system consists of (8), PID controller with interface (7), opto-thyristor of symmetrical and electric heaters (2). The air movement is carried out by means of a centrifugal fan (3) of medium pressure on the system of air ducts. 


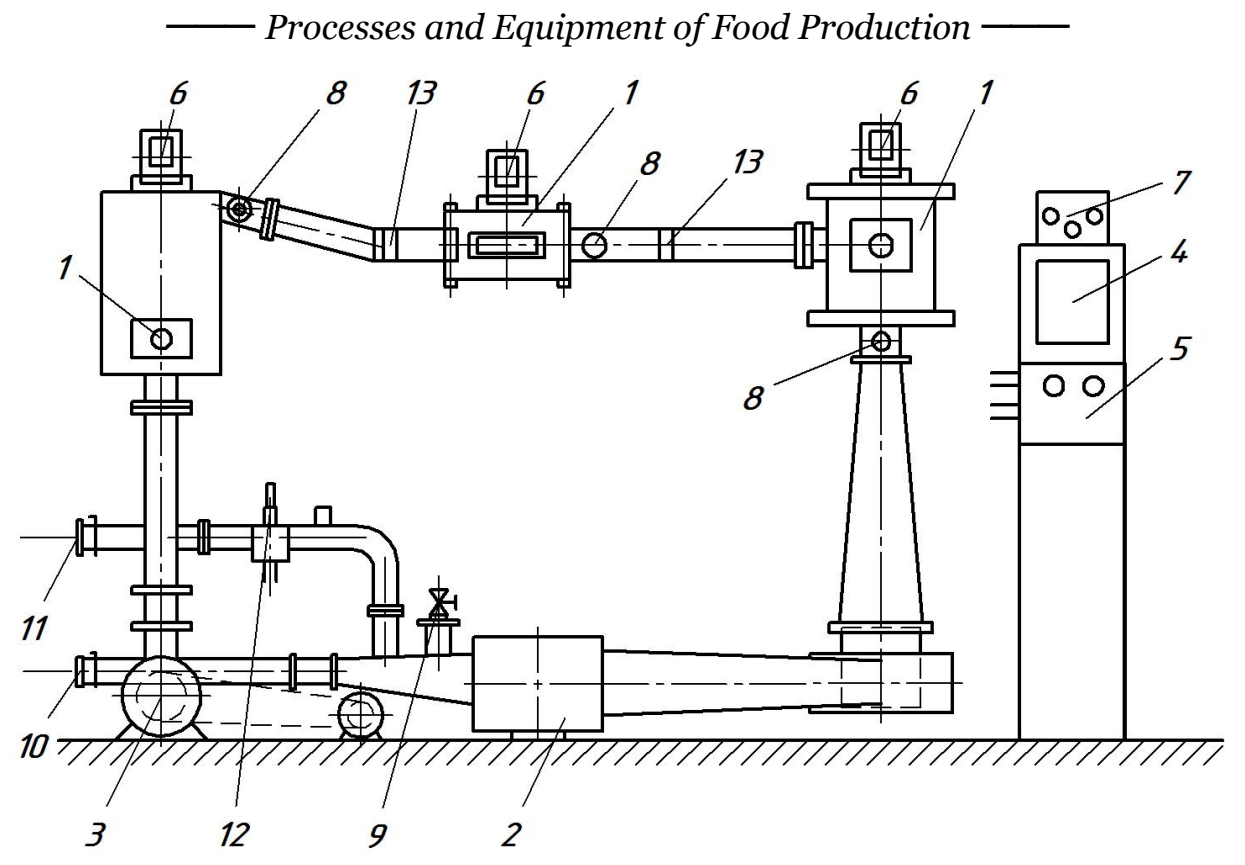

Figure 1. Scheme of the experimental stand:

1 - drying chambers; 2 - heater; 3 - fan; 4 - potentiometer; 5 - control panel;

6, 7 - automatic temperature control system; 8 - resistance thermometers; 9, 10, 11 - pipe fittings; 12 - psychrometer, 13 - special lattices.

The change in the velocity of the heat carrier is achieved by controlling the number of revolutions of the fan's working wheel by means of the frequency controller, the ratio between the spent and fresh air can be adjusted with the help of shibers on the nozzles ( 9 , $10,11)$.

The air temperature in the drying chamber is recorded using a chromole-copulative thermoelectric converter with a diameter of $0.2 \mathrm{~mm}$, located above the samples under study. During the drying process, the temperature of the surface of the sample and its central part was measured using specially made probes with a diameter of $1.2 \mathrm{~mm}$ with thermoelectric chromed-coplanar converters mounted in them.

\section{Results and discussion}

\section{Investigation of the kinetics of the drying process of soybean - vegetable compositions}

In the processing of plant material with prolonged storage there is a partial destruction of biologically active components (BAC) and a decrease in the functional value of the final product [7]. Therefore, it is advisable to study the kinetics of drying of soybean and vegetable components for the further development of energy-efficient drying regimes and prevention of losses of the BAC under the influence of temperature of the coolant. The subject of the study is hygrothermically processed soy [8], carrot and spinach, as well as compositions - soybean-spinach and soy-carrot.

Experimental studies were carried out on the drying of a soybean-carrot mixture with 
temperatures of the heat-coolant 70 and $100{ }^{\circ} \mathrm{C}$, the results of which are shown in Figure 2 . The process of drying the binary mixture takes place in the second period. With the deepening of the evaporation zone inside the material, the temperature of its surface increases, and the rate of moisture decreases. The rates of drying curves show that with the increase of coolant, the intensity of dehydration increases. However, the use of a hightemperature drying regime at $100^{\circ} \mathrm{C}$ results in an undesirable melayidine reaction, which results in the burnout of biologically active substances, changing qualitative characteristics of the raw material, with a significant highlighting of the color of the raw material.

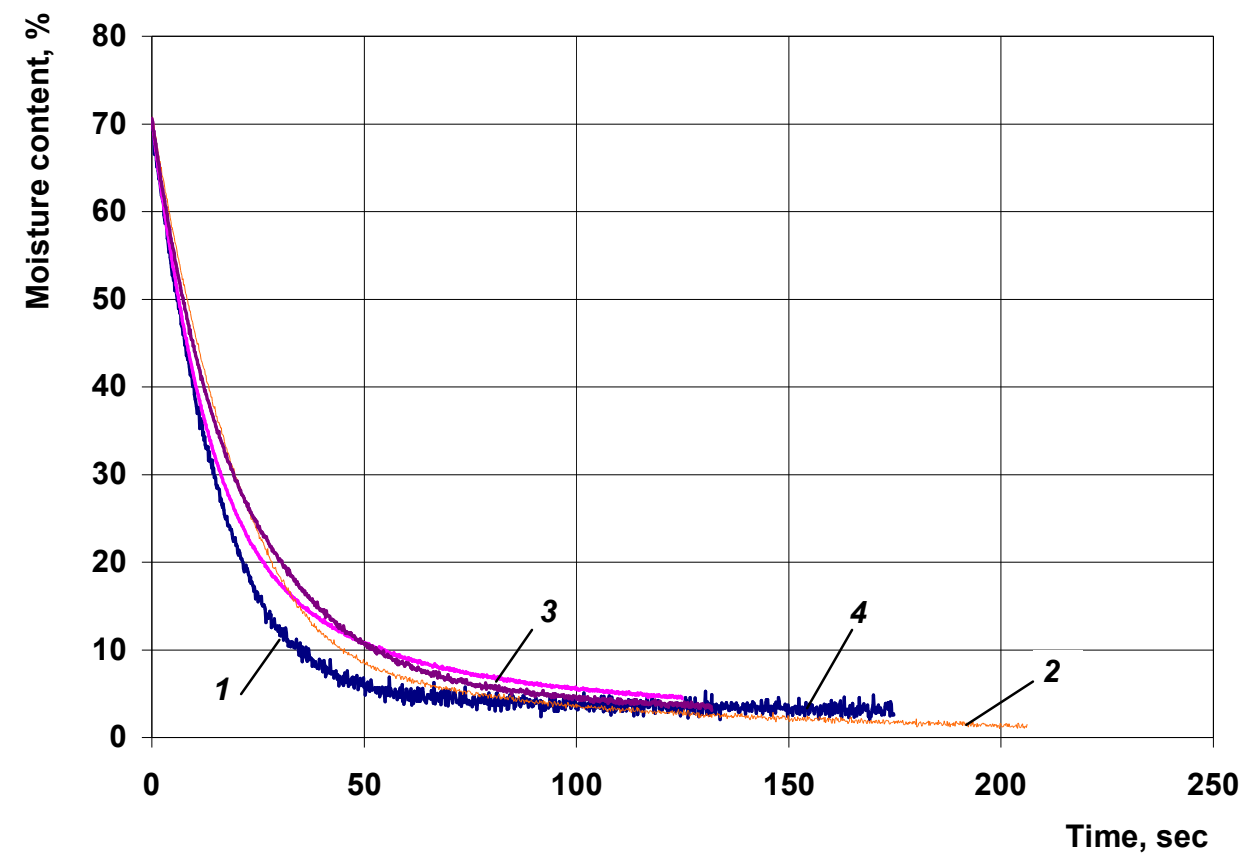

Figure 2. Curves of drying of soybean-carrot mixture according to step-by-step regimes $\delta=10 \mathrm{~mm}, W_{\mathrm{K}}^{\mathrm{c}}=4 \% ; V=2,5 \mathrm{~m} / \mathrm{sec} ; d=10 \mathrm{~g} / \mathrm{kg}$ dry pr.:

1 - carrot $70{ }^{\circ} \mathrm{C}, 2-\operatorname{soybean}-\operatorname{carrot} 70^{\circ} \mathrm{C}, 3$ - soybean-carrot $100 / 70^{\circ} \mathrm{C}, 4-\operatorname{soybean} 70^{\circ} \mathrm{C}$

For the study of phytoestrogenic raw materials, a combination of soy was selected spinach treated with hygrothermically. Folic acid (vitamin B9) is widespread in nature, but its content in products is very small. Folic acid is easily destroyed by heat treatment at 100 ${ }^{\circ} \mathrm{C}$ for 20 minutes. Its name (folium-sheet) - vitamin received because it was first found in spinach. The shelf life of spinach at a storage temperature of $0-1{ }^{\circ} \mathrm{C}$, relative humidity of $90-95 \%$ for only 2 days. To prolong the shelf life spinach must be preserved, one of the ways to preserve is drying. Before drying spinach, according to the literature data, it is necessary to soak [13]. Experimental studies were carried out on the drying of soy-spinach composition at temperatures of $60^{\circ} \mathrm{C}, 100^{\circ} \mathrm{C}$ and $100^{\circ} / 60^{\circ} \mathrm{C}$. The combined analysis of the data showed that the drying process of the binary mixture takes place in the second period. As the evaporation zone deepens in the middle of the material, the temperature of its surface increases, and the rate of moisture decreases. 
At the beginning of the process (Figure 3), The temperature of the heat-coolant is equal to $100{ }^{\circ} \mathrm{C}$. After $5-10$ minutes the drying temperature of the heat-coolant is reduced to 60 ${ }^{\circ} \mathrm{C}$ (curve 2 in Figure3). For comparison, the curves of drying soy-spinach mixture at $60{ }^{\circ} \mathrm{C}$ (curve 1) are shown in Figure 4. The dried mixture according to the regimes (curves 1,2) has a green color, with the taste of the original raw material.

\section{Heat - mass transfer in the process of drying of soy-vegetable composition}

The use of a high-temperature carrier to intensify the process is limited by the specifics of the material being studied. Generalization of the curves of drying kinetics in a semi logarithmic coordinate system following the technique of Krasnikova V. allowed to determine the critical moisture content of binary mixtures. The first critical moisture content is $45-60$, and the second $18-25 \%$ moisture content of the material and depends on the conditions of the experiment.

After the kinetics results, the moisture content is easily transferred to the calculation of the kinetics of heat exchange of binary mixtures in order to determine the optimum drying regimes. The method of graphical differentiation - curves $t-W$ is used to calculate the temperature coefficient of drying, and the Rebinder number. In addition, dependencies are built. The nature of their variation by different drying regimes turned out to be similar (Figure 5).

When the critical moisture content is reached $\mathrm{W}=45-55 \%$, the number $\mathrm{Rb}$ begins to increase, indicating that most of the heat is lost in heating the material, rather than evaporating moisture out of it. This circumstance proves the necessity of lowering the temperature of the coolant when the material reaches a critical moisture content $\mathrm{W}=45$ $60 \%$. So, it makes no sense to maintain the heat of the heat-coolant at the last stage of the dehydration process. The processing of the experimental data has proved that the number of the Rebinder does not depend on the velocity and moisture content of the heat-coolant, but is determined only by the thermal regime of drying.

\section{Nutrition powders with carotene}

Drying was carried out to a final moisture content of $4 \%$ to obtain a powder. Powders can be used as semi-finished products in various industries of the food industry. On the basis of carotene-containing powders of soy-carrot and soy-spinach mixtures, you can produce the final product. To this end, the technology of obtaining a quick-cooking soup spinach soup has been developed. Dry carotene-containing mixtures of fast-food products have a number of features and benefits.

The process of dosing powder-like components is provided with high accuracy and allows you to create puree-like mixtures with different content of dry substances in products. Fast food products are of high biological value.

Due to its chemical composition, these compositions enhance the physiological functions of the body. They are recommended for medical and preventive and infant nutrition that enrich the diet with vitamins and trace elements, improve the functioning of the digestive system. Natural food fibers actively remove slags and toxins, restore microflora of the stomach and normalize its work. 


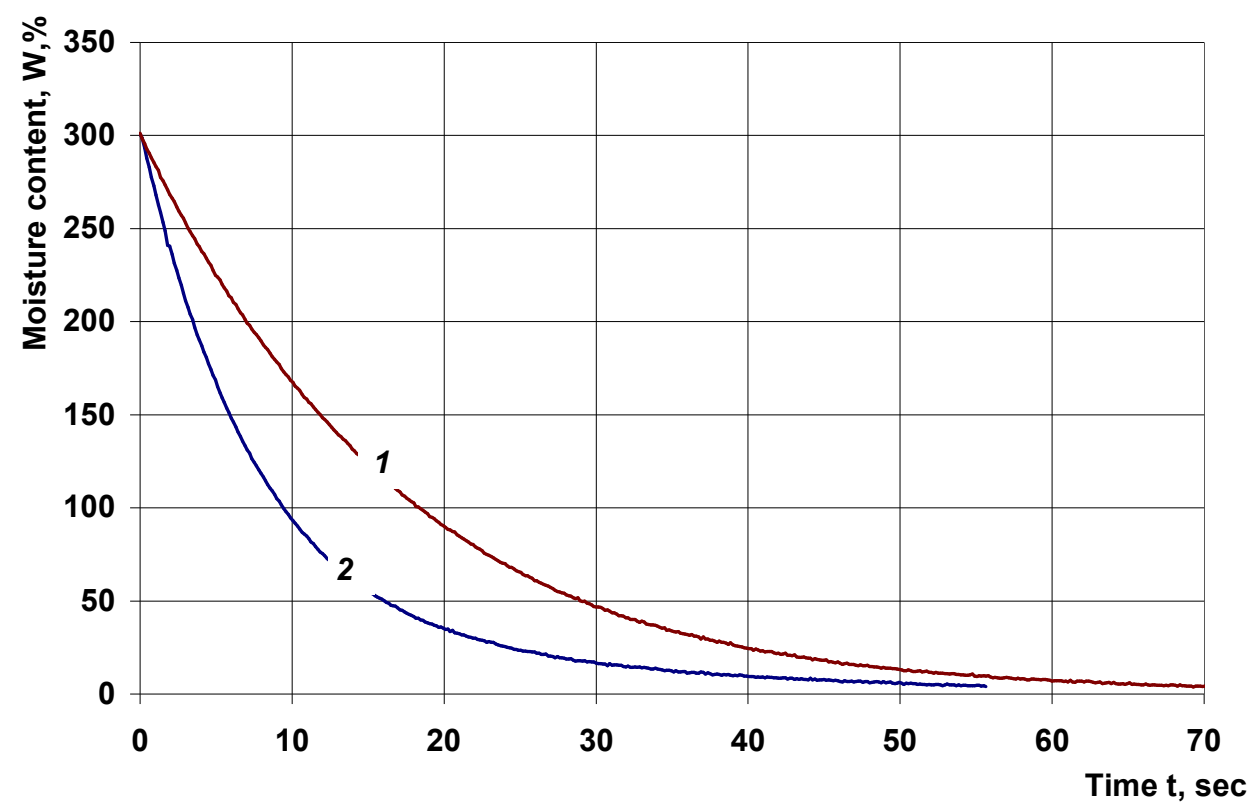

Figure 3. Curves of drying of soy-spinach mixture according to step-by-step regimes $\delta=10 \mathrm{~mm}$, $W_{\mathrm{K}}^{\mathrm{c}}=4 \% ; V=2,5 \mathrm{~m} / \mathrm{sec} ; d=10 \mathrm{~g} / \mathrm{kg}$ dry pr.:

1 - soy-spinach $60^{\circ} \mathrm{C} ; 2$ - soy-spinach $100 / 60^{\circ} \mathrm{C}$

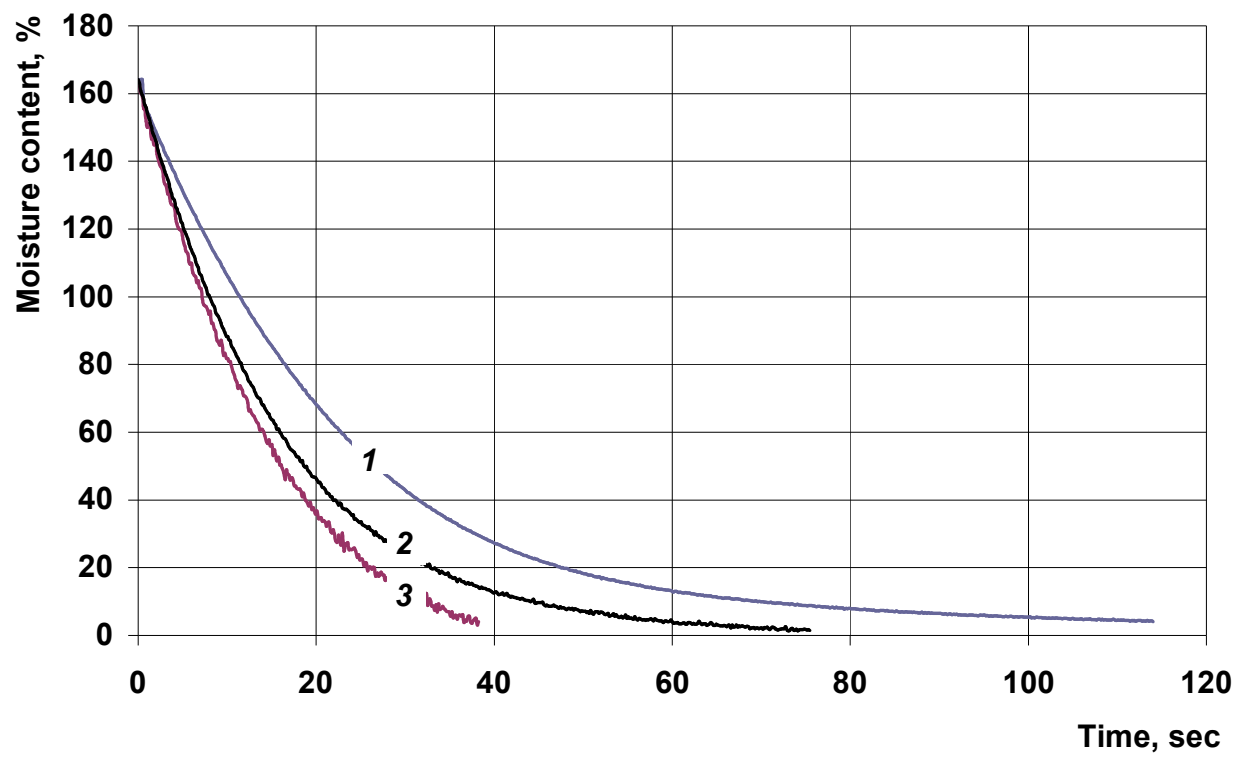

Figure 4. Effect of heat carrier temperature on soybean-spinach mixture drying process $\delta=10 \mathrm{~mm}, W_{\mathrm{k}}^{\mathrm{c}}=4 \% ; V=2,5 \mathrm{~m} / \mathrm{sec} ; d=10 \mathrm{~g} / \mathrm{kg}$ dry pr., $\mathrm{t}=60$ 으:

1 - soy; 2 - soy-spinach; 3 - spinach 


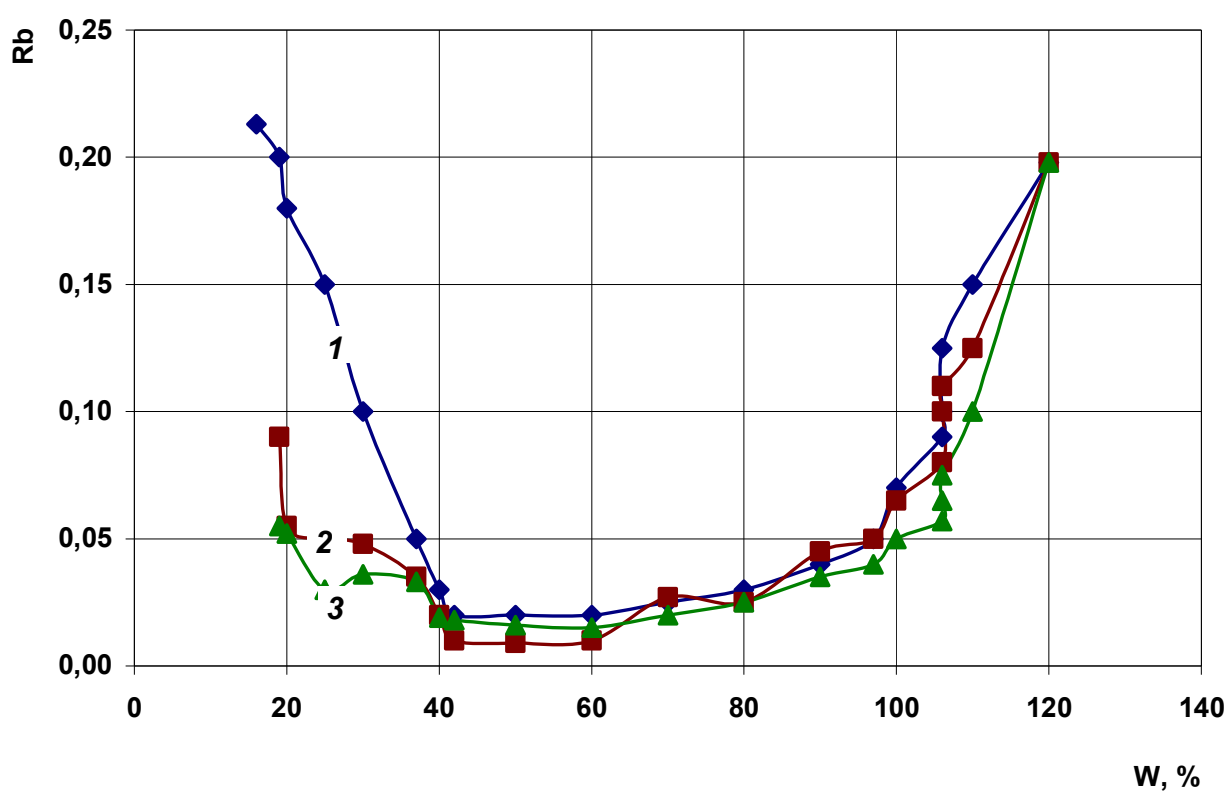

Figure 5. Change in the number of Rebinder in the process of dehydration of soybean-carrot mixture: $V=2 \mathrm{~m} / \mathrm{s} ; \mathrm{d}=10 \mathrm{~g} / \mathrm{kg}$ dry pr.; granule size $10 \times 10 \times 65 \mathrm{~mm}$; soybean and carrot ratio $1: 1$; heat-coolant temperature $t,{ }^{\circ} \mathrm{C}$ :

$$
1-120 ; 2-100 ; 3-80 \text {. }
$$

On the basis of the research conducted, a recipe for soya-pumpkin porridge of quick preparation, in which the soy-pumpkin powder is used, was developed. This allows you to remove dry milk from the formulation, enrich the product with vegetable proteins, increase the shelf life of the dry mixture (Table 1).

Table 1

The chemical composition of soy-pumpkin porridge

\begin{tabular}{|c|l|c|c|}
\hline \multirow{2}{*}{ № } & \multicolumn{2}{|c|}{ Indexes } & \multicolumn{2}{c|}{ Composition } \\
\cline { 3 - 4 } & & $\%$ & $\mathrm{mg}, \%$ \\
\hline 1 & Total sugars & 49,7 & - \\
\hline 2 & Pectin & 1,8 & - \\
\hline 3 & Cellulose & 8,2 & - \\
\hline 4 & Mineral substances & 2,1 & - \\
\hline 5 & Organic acids & 0,4 & - \\
\hline 6 & Protein & 11,0 & - \\
\hline 7 & Fats & 9,0 & - \\
\hline 8 & Starch & 15,5 & - \\
\hline 9 & Nitrogenous substances & 2,3 & - \\
\hline 10 & Carotenoids & - & $2,8-3,5$ \\
\hline
\end{tabular}


Soy-pumpkin porridge enriched with sugar, starch contains all the components that are typical of raw pumpkin and soy. Soy protein effectively improves the total amount of food protein of the product, contains all vital essential amino acids: arginine, histidine, lysine, tryptophan, phenylalanine, methionine, threonine, leucine, isoleucine, valine. Soy-carotene concentrates have a high content of phosphatides - lecithin and cephalin.

The structure of mineral elements includes salts of potassium, phosphorus, magnesium, calcium, copper, iron, manganese, zinc, cobalt and nickel, vitamins A, B, B2, D, E, C, K. Soy-carotene products have high dietetic properties, have antihypo-toxic, hypocholesteromic and hypothermic activity, stimulate the human nervous system, are used in the treatment of diabetes and radiation sickness.

\section{Conclusion}

The carried out researches give the chance to draw a conclusion, that the optimum mode of drying should be the regime, after which the temperature of the material does not exceed $70-80^{\circ} \mathrm{C}$. As the moisture content decreases, the Rebinder value (Rb) decreases, that is, the heat during drying is more expended on evaporation of moisture from the material than on its heating.

The necessity of lowering the coolant temperature at the final stage of the drying process is confirmed, this certainly positively affects the quality of the dried material.

The results of the conducted studies have developed step-by-step regimes for drying the soybean-carrot and soybean-spinace mixture, in which the temperature of the heatcoolant changes during drying, which reduces the energy costs of drying, shortens the drying time and, as a result, preserves the quality of the mix composition, with high longterm storage properties. Also, for the proposed step-by-step regimes, a technology for producing soya-spinach soup with bistro preparations was developed.

\section{References}

1. Shahab Abdulla, Paul Wen, Richard Landers, Yousif B.F. (2011), Fruit drying process: Analysis, modeling and simulation, Scientific Research and Essays, 6(23), pp. 49154924.

2. Marie Céleste Karama, Jeremy Petita, David Zimmera, Elie Baudelaire, Djantoub, Joël Schera (2016), Effects of drying and grinding in production of fruit and vegetable powders: A review, Journal of Food Engineering, 188, pp.32-49.

3. Shahab Abdulla, Paul Wen, Richard Landers, B. F. Yousif (2011), Fruit drying process: Analysis, modeling and simulation, Scientific Research and Essays, 6(23), pp. 4915-4924.

4. Monajjemi M., Nurul Aminin A.L., Ilkhani A.R., Mollaamin F. (2012), Nano study of antioxidant activities of fermented soy whey prepared with lactic acid bacteria and kefir, African Journal of Microbiology Research, 6(2), pp. 426-430.

5. Zanhi N.K., Jideani I.A. (2012), Physico-chemical and sensory qualities of soy and milk solids fortified low fat yoghurt, African Journal of Agricultural Research, Vol. 7(38), pp. 5336-5343.

6. Bhagavathy S., Sumathi P (2012), Stabilization of membrane bound ATPases and lipid peroxidation by carotenoids from Chlorococcum humicola in Benzo(a)pyrene induced toxicity, Asian Pac J Trop Biomed, 2(5), pp. 380-384. 
7. Sniezhkin Yu.F., Petrova Zh.O. (2007), Teplomasoobminni protsesy pid chas oderzhannia karotynovmisnykh poroshkiv, Akademperiodyka, Kyiv.

8. Zhanna Petrova, Yurii Snezhkin, Kateryna Slobodianiuk(2016), Drying of the composite phytoestrogen materials, Ukrainian Journal of Food Science, 4(1), pp. 104110.

9. Hany El-Shemy (2011), Soybean and Nutrition, InTech, Rijeka.

10. Krishan Datt Sharma, Swati Karki, Narayan Singh Thakur, Surekha Attri (2012), Chemical composition, functional properties and processing of carrot - a review, $J$ Food Sci Technol, 49(1), pp. 22-32.

11. Liat Lomnitski, Margalit Bergman, Abraham Nyska, Varda Ben-Shaul, Shlomo Grossman (2003), Composition, Efficacy, and Safety of Spinach Extracts, Nutrition and cancer, 46(2), pp. 222-231.

12. Snezhkyn Yu.F., Paziuk V.M., Petrova Zh.O., Mykhailyk T.O. (2010), Issledovanie vliianie parametrov na kinetiku i vskhozhest semian rapsa, Industrial heat engineering, 3(32), pp. 37-42.

13. Snezhkyn Yu.F., Petrova Zh.A., Paziuk V.M. (2016), Energoeffektivnye teplotekhnilogii proizvodstva funktsionalnykh pishchevykh poroshkov, VNAU, Vinnytsia.

14. Vyacheslav Mykhailyk, Sviatoslav Lementar, Roman Yakobchuk, Yevhen Skrynnyk, Roman Semenko (2016), Wheat grain drying kinetics in a thin layer, Ukrainian Journal of Food Science, 4(2), pp. 316-326. 